\title{
Holy Death in the Time of Coronavirus: Santa Muerte, the Salubrious Saint
}

\section{Kate Kingsbury ${ }^{1}$ (D) R. Andrew Chesnut $^{2}$}

Received: 9 June 2020 / Accepted: 18 August 2020 /Published online: 11 September 2020

(C) Springer Nature Switzerland AG 2020

\begin{abstract}
As Santa Muerte prayer cards and candles circulate in Mexico with petitions of protection against COVID-19, we consider death as doctor in these tumultuous times proving that the folk saint of death is not solely a narco-saint, as the press depicts, but is supplicated for miracles of COVID healing and protection from the virus. We not only reveal the importance of religion for coping with pandemics but also focus on the notion of death as healing and as a giver of life. We decolonize knowledge of Santa Muerte and explore the saint's syncretic origins, hailing not only from the European Grim Reaper during times of plague but also from Indigenous thanatological epistemologies that account for her dual powers of gifting life and also doling out death.
\end{abstract}

Keywords Santa Muerte $\cdot$ Coronavirus $\cdot$ Mexico $\cdot$ Healing $\cdot$ Folk saint $\cdot$ Death

Across the world, as of early 2020, many countries announced a lockdown, some even declaring a state of emergency due to coronavirus. COVID-19 is a potentially deadly respiratory disease that is highly contagious and has killed hundreds of thousands of people, with no known cure. Citizens in most countries across the globe have been encouraged to maintain social distancing, namely to keep a two metre space between themselves and people other than those within their households at all times. They have also been ordered to stay at home and in some countries businesses other than those considered essential, such as restaurants and hairdressers, have been instructed to close their doors. These and other measures have been taken as governments and citizens seek to quell the virus' reach. Although effective in preventing widespread contagion,

Kate Kingsbury

kingsbur@ualberta.ca

R. Andrew Chesnut

rachesnut@vcu.edu

1 Anthropology Department, University of Alberta, Edmonton, Canada

2 School of World Studies, Virginia Commonwealth University, Richmond, VA, USA 
such actions have severely impacted the economy and the livelihoods of many. The paranoia and panic over the pandemic in many nations, such as Mexico, are the result of the convergence of governmental incompetence, conspiracy theories and the fear of serious illness and death.

All living beings must inevitably perish; nevertheless, across the ages, human beings have seldom accepted their mortality nor that of their loved ones. And religion has long served as a means to seek to avoid disease and death or come to terms with it, whether in Mexico, Brazil (Chesnut and Kingsbury 2019) or elsewhere in Latin America. One of Jesus' principal roles was as healer, one could even term him a shaman as Craffert has, positing that his main roles were curing, mediating and prophecy (Craffert 2010).

This article stresses the importance of looking at religion in times of pandemic as a coping mechanism. Additionally, focusing on Santa Muerte, the saint of death in times of coronavirus, it demonstrates that even death, as a perceived supernatural power, can heal and prolong life. This is an ancient idea but one that has received scant recent academic attention. ${ }^{1}$ Furthermore, the idea has often been at odds with those from within Christian traditions for whom death is about finality; nevertheless, in Mesoamerica, the idea of death as regenerative of life is ancient.

In Mexico, many pre-Hispanic death deities, although also symbolizing the realms of the underworld or acting as psychopomps, were propitiated or appeased to delay death and even bring sanation (Miller and Taube 1997). Ah Puch was a Mayan death deity found in the codices associated with pestilence (Guerra 1964). In pre-Columbian times, if death visited a Mayan household, it was believed that wailing would prevent Ah Puch from taking another soul. Centuries later, death is still being propitiated for protection and healing from COVID-19, his time in the form of Santa Muerte, a modern day female folk saint of death. Furthermore, those Mexicans who have lost their jobs and are facing trials and tribulations are also turning to this saint to cope with the mental strains. In a country where the state does not have a lid on the plague of narco-violence, let alone on the coronavirus pandemic (see Burki 2020), those who worry about falling ill have few options but to turn to death for life.

As purveyors of religious paraphernalia have been quick to respond to the robust new market for Santa Muerte prayer cards and candles that feature petitions of protection against COVID-19, we consider death as doctor in these tumultuous times. We begin by describing Santa Muerte's attributes, after which we consider her origins. We argue that they derive not only from pre-Hispanic thanatology but also hail from the dark days of the Black Death in fourteenth-century Europe. Without such an understanding of not only her European but also her Indigenous origins, the duality of her powers of life and death cannot be comprehended. We then outline praxis and belief in devotion to death. In turn, ethnographic evidence is proffered detailing Santa Muerte's role in the coronavirus pandemic. This underscores not only her role as holy healer, countering claims she is merely a narco-saint but also attests to the saint's plasticity in adapting to l'air du temps. We also consider how veneration of Santa Muerte allows her devotees to be willing to take her bony hand when the time comes for them to leave this world. As we outline, the new religious movement is based, much

\footnotetext{
${ }^{1}$ Unless scholars are looking at ancient practices through the lens of archaeological findings. We suggest that no studies exist of this idea still in practice today. The most recent large-scale work on this was by Bloch and Parry in Bloch and Parry 1982 in their book 'Death and the Regeneration of Life'.
} 
as Indigenous faith once was, upon acceptance of the interdependence of life and death. For devotees, this thanatological epistemology furnishes the framework for understanding their reality and the certainty of death.

\section{Our Methodology}

We are a research team of two. One of us is an anthropologist who has been doing fieldwork in southern Mexico on Santa Muerte for three years. The other is a religious studies specialist who authored the first academic book in English on what is now the fastest growing new religious movement in the Americas and has spent the past eleven years researching the skeleton saint. The anthropologist during fieldwork made strong local connections which they maintain and although unable to go to the field due to current travel bans owing to the virus, they are in contact daily with respondents in Mexico and abreast of what is happening on the ground. Furthermore, both of us have conducted digital ethnography using participant observation to interact with Santa Muertistas (devotees of Santa Muerte) on social media sites such as Facebook which has innumerable groups consisting of 80,000 followers in some groups alone. On these sites, we publicly and privately corresponded with those posting prayers against COVID-19 and those thanking Santa Muerte for miracles of virus healing. We informally asked about their experiences, the practices and beliefs in non-biased, unstructured conversations.

\section{Santa Muerte}

Whether in the form of a silver pendant, a plaster statue or a votive candle, or a golden medallion, Santa Muerte is most nearly always represented as a Grim Reapress. She has a skull, instead of a fleshy face, is garbed in a long gown and wields a large scythe in her left hand. The name 'Santa Muerte' reveals her identity. Muerte means 'death' in Spanish and 'Santa' refers to both her holiness and her role as a saint. In their rituals, such as the Rosary of Santa Muerte, devotees often call her 'Santísima Muerte' which literally translates as 'holiest death.' In English, she is called Saint Death or Holy Death.

Santa Muerte is a folk saint. Unlike Catholic saints, who have been canonized by the Church, folk saints are spirits of the deceased who have not obtained official recognition but are believed by the local populace to possess supernatural powers and be able to deliver miracles. As Graziano points out 'the world of folk saint devotion ... is one in which supernatural beings ... are a prominent presence in everyday life. They intermingle with humans and have causal influence-magical and miraculous' (Graziano 2006, p. 6).

Santa Muerte has often been erroneously portrayed by the press, media and US law enforcement authorities as a narco-saint, that is to say a saint venerated solely by narcotraffickers (Kingsbury and Chesnut 2020a; Kingsbury 2020). In a previous paper, we demonstrated how this is a fallacious depiction and revealed her role as matron saint of the drug war being supplicated by both sides of the law, but the saint of death's role extends far from doling out justice or exacting revenge on foes. Holy Death has long 
been turned to for health and healing by her devotees, earning her the moniker 'la Santa Sanadora' (the salubrious saint) in reference to her role as supernatural 'curandera' (folk healer).

Folk saints in Latin America have often been appealed to by devotees to cure their ailments. In Mexico and Latin America in general, vernacular saints like Jesús Malverde, Niño Fidencio, and Rey Pascual are frequently favoured above Catholic saints in prayers for well-being. God may seem to be a deus otiosus, a figure who although powerful is aloof and uninvolved, therefore making him difficult to propitiate or enter into an intimate relationship with (Kingsbury and Chesnut 2020a). Catholic saints, the great majority of whom lived centuries ago in Europe, are far removed from the average Latin American and are difficult to relate to, although Saint Jude, patron of lost causes, has become hugely popular in Mexico. Folk saints, literally saints of the folk, are typically deceased people who lived out their lives on local soil and who after their death are believed to have been gifted supernatural powers (Graziano 2006). Due to cultural affinities and familiar life stories, they are perceived as being more likely to listen to, understand and resolve the problems of their followers (Kingsbury and Chesnut 2020a; Kingsbury 2020).

Niño Fidencio, who lived in the northern Mexican state of Nuevo León in the first decades of the twentieth century, was a renowned faith healer before he expired and became a saint propitiated by the sick (Agostoni 2018). In a similar vein, Pedro Bastista, during the same period, presided over a quasi-Catholic commune in the backlands of Brazil based on the promise of the supernatural healing of earthly afflictions (Chesnut 2017; Pessar 2004). It therefore would not be far-fetched to argue that the most popular saints in the region are generally those that have a reputation for being powerful healers. Santa Muerte is also said to have strong curative powers, and as we will detail, is currently being propitiated to heal and protect devotees from COVID19. As this is a new religious movement that has emerged in the last two decades in response to present day needs (Chesnut 2017; Kingsbury and Chesnut 2020a, 2020b), it is in perpetuum mobile and has manifested once more its malleability by morphing to Mexicans' current necessities in these times of coronavirus.

\section{The Reaper of Black Death}

Most Americans and Western Europeans would immediately recognize Santa Muerte as a sort of female Grim Reaper with origins in medieval Catholicism. Spaniards would not even have to make allowances for her gender since their own personification of death, known as 'la Parca' (the parched one), is a female skeleton. Mexicans devotees, however, are more likely to regard the skeleton saint as an adapted version of an Indigenous goddess of death, whether Aztec, Mayan or Purépecha. As odd as this may seem to foreign observers, for many Mexicans the realities of Indigenous history and the myths of nationalism converge to give the folk saint a local birthplace in preColumbian Mexico.

In the capital city, the most common version of the story of the saint's Indigenous identity highlights her purported Aztec origins. More specifically, Santa Muerte is thought to have originated as Mictecacihuatl, the Aztec goddess of death who along with her husband, Mictlantecuhtli, ruled over the underworld, Mictlan. Like Santa 
Muerte, the deathly couple was typically represented as skeletons or human bodies with skulls for heads. Aztecs not only believed that those who died of natural causes ended up in Mictlan but also invoked the gods' supernatural powers for earthly causes, such as healing. With its persecution of Indigenous religion, the Spanish Conquest drove devotion underground and into syncretism with Catholicism. Thus, according to this version, her Spanish style tunics and dresses, and her European accoutrements, the scythe and scales of justice, are but a façade thinly veiling her true Aztec identity (Chesnut 2017, p. 22).

Both the few Mexican academics who have studied her and the former cult godfather, David Romo, trace the folk saint's origins to medieval Western Europe (Lomnitz 2005, Malvido 2005). The Mexican anthropologist Katia Perdigón Castañeda, for instance, writes, 'The history of the present concept of death and its iconography, reflected in the contemporary Santa Muerte, are more related to JudeoChristian religion (Catholicism in this particular case) than the forgotten and unknown voices of the vanquished, in other words, the pre-Hispanic peoples' (Perdigón Castañeda 2008). David Romo and others specifically locate the genesis of the saint in the figure of the Grim Reaper of medieval European Catholicism.

The Grim Reaper originated during a pandemic not entirely dissimilar to the one we are now experiencing, albeit with today's advanced medical care and knowledge of how diseases spread we are better equipped to deal with the latest epidemic. The Black Death, also known as the bubonic plague and the Pestilence, was a deadly disease that attacked the lymphatic system causing buboes, swollen lymph nodes (Cohn and Cohn 2003). Caused by the bacterium Yersinia Pestis, it eventually attacked the lungs leading to a gruesome death. It devastated Europe and Asia in the mid-1300s (Horrox 2013).

The bubonic plague, akin to COVID-19, spread to Europe via people travelling from infected towns and cities abroad (ibid.). Much like today, when cruise ships were believed to be one of the first and worst hit places due to the nature of enclosed crowded spaces which allowed COVID-19 to spread to passengers who then infected others upon their return home, back in the fourteenth century ships were believed to be the key vector of infection (Sonne 2016). In the early 1340s, the disease struck China, India, Syria, Persia and Egypt. In 1347, contagious travellers arrived in Europe from Caffa, Crimea. Twelve ships entered the Sicilian port of Messina. Those waiting on the docks were shocked to find that many aboard the ships were dead. Others were severely ill and covered in black boils which exuded pus and blood. Local authorities demanded the fleet of so-called death ships leave the harbour, but it was too late, the pestilence had already begun to spread. From Italy, the disease gradually propagated across the rest of Europe (Cohn and Cohn 2003).

Over the next five years, the Black Death would claim more than 20 million lives in Europe (Cohn 2008). The bubonic plague thus made death and the dying a familiar presence for fourteenth-century Europeans. During this time, when at least one-third of the populace died from the plague, death became ubiquitously personified in Europe as the skeletal figure we know today (Guthke 1999, p. 48, Van Marle 1971, p. 361-363). According to Bramley, 'terrifying figures' with scythes were observed in European communities at people's doors, the inhabitants of which fell ill (Bramley 1990, p. 210). It is from such reports combined with the imagination of painters and sculptors that the skeletal figure of the Grim Reaper emerged. For some, this figure was synonymous with the Devil. 
The robe is believed to represent the vestments that religious figures at that time wore when conducting funerary rites. The scythe is symbolic. It derives from mythological traditions of Ancient Greece in which life is imagined to be a thread that can be cut short (Dietrich 1965). The Greeks envisaged three sisters, the Fates, who meted out life and death to each individual, Clotho (the Spinner), Lachesis (the Apportioner) and Atropos (the Inflexible). Clotho held the distaff of the thread of life, intertwining dark and light strands. Lachesis, the second sister, twisted out the cord, and beneath her fingers, it vacillated strong and weak with life's vicissitudes. Atropos, the oldest, armed with a large pair of shears, cut the thread of life (ibid.).

Peasants in the fourteenth centuries used scythes and sickles to cull their harvests and analogously death was imagined as scythe-wielding rather than shears-holding. It was said that death culled the living thus cutting their existence short, much as farmers in their fields lopped the heads off their wheat and barley crops. The practice began of decorating churches and graveyards with the ominous skeletal figure. In one of the most vivid depictions of death, usually set in cemeteries, Catholic clerics had actors perform a 'danse macabre', a dance of death. One of the thespians would dress as Death and as the other performers swayed their bodies one last time the Grim Reaper approached them, scythe in hand, and snatched up their soul (Knoll and Oosterwijk 2011). The Grim Reaper along with skulls featured in a wide range of religious material culture. The aim was to ensure that Christian eschatology be more easily assimilated by lay people. In the $1500 \mathrm{~s}$, such iconography would evolve into memento mori and vanitas items and objects (Schmidt 2011, p. 261).

\section{Death in the New World}

Spanish clergy employed the female figure of the Grim Reaper, la Parca, in a similar didactic fashion among the Indigenous peoples of the Americas. When they arrived in the New World, they sought to convert locals to Christianity and thus 'save their souls' (Megged 1996). They bought figures with them of Jesus, Mary and various saints as well as la Parca as pedagogic tools. Interpreting Christianity through their own cultural lens and drawing on their own traditions of venerating not only the spirits of the deceased but also, as we saw in the introduction to this paper, propitiating death deities for earthly needs, some Indigenous groups, such as the highland Maya in the state of Chiapas and Guatemala, and the Guarani in Argentina and Paraguay, took the Church's skeletal figure of death for a saint in its own right and began worshipping it (Chesnut 2017, p. 48).

Across pre-Hispanic Mexico, Indigenous peoples from the Aztec to the Zapotec, as detailed in the introduction, practiced ancestor worship and also venerated death deities (Jansen and Jiménez 2017; Lind 2015; Rivard 2012). In pre-conquest iconography there are myriad skeletal deities from Ah Puch, the cadaverous Mayan death god, to the Tarascan goddess of birth and demise, Cuerauaperi, who has a skull for a head and empty death-like eyes (Hosier 1995; Pollard 1993). Many of these death deities, from Mictecahihuatl to Xonaxi Quecuya, not only acted as psychopomps but also had the power to gift and 'foment life' (McCafferty and Carrasco 2001, p. 319). And indeed many death goddesses were depicted in late pregnancy signifying the fecundity of death as a 'source of life' (Bloch and Parry 1982, p. 6-7). Death, rather than spelling 
finality as in Christian theology, was linked across Indigenous mythologies with the regeneration of life, as in the Mayan ball game, which is an analogy in action of 'death and rebirth' (Schele and Freidel 1990, p. 76).

In Christian eschatology, the understanding of death was dissimilar. For the Spanish and European Catholics in general, death equated to finality for all except Jesus who triumphed over death salvifically ensuring the possibility of redemption for all believers (Brondos 2001). In the New World, la Parca was conceived by some Indigenous people through the lens of their own thanatological traditions who rather than seeing Jesus as victorious over death, viewed death as prepotent or even fused the two together seeing both as mystical personages. Wishing to gain access to death's awesome powerwhich as we have seen in Indigenous thanatology is linked to life-some began to venerate the skeletal figures brought by the Spanish. Many iterations of death worship emerged as syncretic figures, amalgamating both Indigenous thanatology, Christian hagiology and iconography.

In Guatemala, in 1650 the vernacular saint Rey (King) Pascual, a skeleton with a crown atop his skull emerged from the concresence of the seventeenth-century Spanish Franciscan saint Pascual Bailón with Mayan religion as well as a popular image of death known as "King Death" that had travelled from Spain to the New World in which death was depicted as a monarch garbed with a crown. This is alluded to in Don Quixote where in "Las Cortes de la Muerte" King Death holds court, his audience a motley crew from all walks of life (Cervantes 1605, part 2, ch 11). Although the Spanish friar never visited the Mayans of Guatemala in his lifetime, he is said to have appeared as death incarnate in a vision to a prominent Mayan villager in the $1650 \mathrm{~s}$ prior to his canonization - in the midst of a virulent plague, which he is credited with ending. In this story, we see the vestiges of Indigenous thanatology wherein death gives life. Thereafter, despite the Church's demands that devotees apostatize, they began to propitiate the figure for miracles, especially those of healing and they do so till this day.

Specific references to actual worship of Saint Death first appear in the Spanish colonial record in the 1790s, almost a century and half later than Rey Pascual. A 1797 document titled 'Concerning the Superstitions of Various Indians from the Town of San Luis de la Paz', within the archives of the Inquisition, mentions Santa Muerte for the first time. Focusing on the Chichimec people of the present-day state of Guanajuato, the Church record speaks of thirty Indians who 'at night gather in their chapel to drink peyote until they lose their minds; they light upside-down candles, some of which are black; they dance with paper dolls; they whip Holy Crosses and also a figure of death that they call Santa Muerte, and they bind it with a wet rope threatening to whip and burn it if it does not perform a miracle'. The clergy's punishment for such 'superstitions' was the destruction of the chapel where the effigy of the saint of death was kept (Perdigón Castañeda 2008, p. 21).

There are also records in 1754 of curanderos being punished for heresy for turning to painted images of death and using these in healing rituals (Perdigón Castañeda 2008, p. 31). Clearly, skeletal imagery - despite the Christian insistence that this symbolized the death of Christ and his triumph over death - was being worshipped by Indigenous people. Images of death were being asked to intervene in earthly causes, in line with pre-Conquest ideals whereby death deities were imagined as being 'involved in the daily routine of life, birth and death' (Harrington 1988, p. 32). 
Inquisition records from the same era and the same central region of New Spain (as Mexico was called in the colonial period) cite a very similar case of 'Indian idolatry'. In this case, however, the skeleton saint is a male figure, who also had his own chapel. In 1793, in the present-day state of Querétaro, a Franciscan friar and vicar filed a complaint against a group of Indians, who in the middle of Mass deposited at the altar 'an idol whose name is the Just Judge and is the figure of a complete human skeleton standing on top of a red surface, wearing a crown and holding a bow and arrow' (Perdigón Castañeda 2008, p. 33). This, along with evidence from Argentina, would seem to point towards an extraordinary fusion of the figure of Christ, the Just Judge, with the image of King Death.

Veneration of such figures often led to severe castigation, from whipping to auto da fe (Tavárez 2011, p. 18). In response to persecution by the Church, devotees of Santa Muerte took their devotion underground. Nevertheless, such practices perdured, even as far north as New Mexico and southern Colorado. In this region, in the 1860s, a group of mestizos were discovered once again worshipping death. This syncretic iteration of death worship emerged from the practice of using death carts by the Penitentes, a Catholic brotherhood which originated in Spain but morphed into practitioners of heteropraxy on the far-flung northern frontier of what had been until recently the Viceroy of New Spain.

The Penitentes used death carts as an instrument of penance. The small, wheeled contraption was loaded with heavy rocks upon which rode the allegorical figure of death in the guise of a female skeleton. It was then pulled by one of the members of the brotherhood. In Spain, the death cart served as a tool in the re-enactment of the Passion of Christ. However, in the New World, the figure of death fused with Saint Sebastian and the Indigenous predilection for devotion to death to create Doña Sebastiana, a supernatural personification of death (Chesnut 2020). This figure was venerated and referred to interchangeably as Santa Muerte and Comadre (co-godmother) Sebastiana. Indeed, a prayer in which Comrade Sebastiana is referred to as Santa Muerte reveals she was petitioned for not only legal favours but also health and healing.

Now Holy Death (Santa Muerte) comes dressed as a woman lawyer to defend this cause of the Lord turned into a sacrament.

My Godmother Sebastiana, crucified, lays out that pathway to God she has travelled on her knees.

Holy Death has set out, riding in her cart; with God's orders, she represents the souls.

Now Holy Death sets out to visit a sick man; commending his soul to God so that he might be freed from hell.

For 40 days, she was prostrate on Calvary accompanying Jesus, my Godmother Sebastiana.

Now they pray a rosary for her prostrate on Calvary; my Godmother Sebastiana gives her blessing (Steele 2005, p. 298).

Mexicans declared independence from Spain, lost a war against the USA and fought in the twentieth century's first great revolution. No doubt many iterations of death remained clandestinely worshipped by devotees, but neither Mexicans nor foreign observers recorded the presence of Saint Death again until the 1940s when two American anthropologists note the saint of death being worshipped by women who prayed to her asking her to use her scythe to return errant husbands to the homestead (Lewis 1961, Toor 1947). Nevertheless, in 
one of the prayers for the novena (nine-day prayer) recorded in a chapbook at the time, the saint is supplicated for sanation. Saint Death is asked not only to rid curses but also illnesses. And of course, curses in Mexican folk epistemology are often perceived to lead to illness (see Zavaleta and Salinas Jr 2009).

\section{Death Goes Public}

By the 1990s, the saint of death had developed into a multi-faceted miracle worker who could be propitiated for any number of favours from financial success to health problems (Chesnut 2017; Kingsbury and Chesnut 2020a; Kingsbury and Chesnut 2020b; Pansters 2019). At this time, small- and large-scale effigies of the saint began to be sold in Mercado Sonora, the 'witchcraft market' located in the Mexican capital. One of the people who bought a statue was the son of a woman known as Enriqueta Romero, affectionately called Doña Queta (Argyriadis 2016, p. 39, 20 Kristensen 2014). She is now a legendary figure among Santa Muerte devotees as she is the person who took what was previously a covert religious folk faith from the shadows into public light when she established a street altar to Santa Muerte in front of her home in Tepito, Mexico City, in 2001. The life-size effigy of Santa Muerte that graced the sidewalk outside her home quickly became a devotional icon for thousands of 'chilangos' (argot for residents of Mexico City).

The statue had been gifted to her by one of her sons to thank the saint for his speedy manumission from jail. It sat in the corner of her kitchen where she sold quesadillas to locals. Seeing the statue many asked to leave devotional items, such as flowers and votive candles. The smoke from the myriad burning flames became so thick and oppressive that Enriqueta decided to move the effigy curbside in November 2001. Since that time, devotion to death has gone public with Santa Muertistas openly acknowledging their faith, and it is estimated that in the last decade, the folk saint has acquired some 7.5 million devotees in Mexico alone (Chesnut 2017).

Enriqueta holds rosaries to honour Santa Muerte every first of the month which attract innumerable devotees to her shrine (see Roush 2014). Since the outbreak, these have not been cancelled despite warnings that large gatherings should be avoided to prevent the spread of COVID-19. On June 1, families, as usual, assembled en masse forming a thick throng, some masked and some not. These devotees came to offer gifts from figurines to liquor. Many approached the shrine on their knees. Upon their arrival, they stretched out prostrate in prayer before a large Santa Muerte effigy dressed in a lavish teal taffeta gown with ivory embroidery. Eder, concerned about coronavirus, explained that Holy Death had helped him with 'a nephew's health problems' as well as 'personal, legal things'.

\section{Holy Death's Doxology}

Santa Muerte is informally structured as a folk faith and there is no single, overarching Holy Death Church equivalent to the Catholic Church. ${ }^{2}$ Although shrines have been

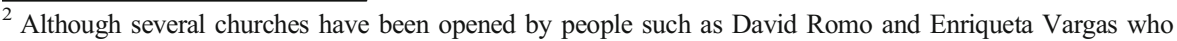
have attempted to create national and even transnational networks of believers, these are exceptions to the rule.
} 
opened by various independent religious entrepreneurs, such as Enriqueta Romero, there is no official clergy or other administrative body overseeing the folk faith. Even if devotees visit shrines to pay their respects to the folk saint, as will be described, they largely practice the faith within the privacy of their own homes, at altars that they have assembled. The non-regulated aspects of the faith, which entail that anyone can practice it freely from the comfort of their home without outside intermediaries, such as priests, make it appealing to a motley crew, comprising people from all walks of life, from bartenders to police officers (Chesnut 2017, Pansters 2019, Yllescas Illescas 2016, 6869). Even if many devotees also worship God, for those we spoke to Santa Muerte as the personification of death is ultimately the most omnipotent. As Vania, a Santa Muerte devotee in Oaxaca detailed, 'la fuerza más poderosa es la muerte, porque lo unico seguro es la muerte', the most powerful force is death, because the only certainty is death (see Kingsbury 2020).

The faith does not have a foundational scripture like the Bible although prayer books and spell tomes circulate freely. The most famous of these is 'la Biblia de la Santa Muerte' or the Bible of Santa Muerte (Rey 2009). Despite the faith being informal and characterized by heteropraxy, there are certain ritualistic and liturgical cornerstones. Altars and shrines are fundamental to the faith. Most devotees have an altar in their house. This may be ornate or merely consist of a small statue of Santa Muerte or even just a votive with offerings to the folk saint consisting of all or some of the following: alcohol (often tequila), flowers, foods such as chocolate and candy, cigarettes, and glasses or bottles of water as the skeletal saint, like her forebear la Parca, is said to be perpetually parched.

One devotee whom we spoke to online who had posted prayers to Santa Muerte and pictures of her modest altar was from a very poor family living in the Mexican capital. We will call her Marisela. She did not have the funds for a statue. Instead Marisela had placed a small printed image of Holy Death dressed in a white robe on a shelf with a miniature skull carved from wood together with offerings of an apple, incense and a cigarette. She prayed at her altar daily to death and told us 'I have asked her (Santa Muerte) to take away coronavirus, I have faith in her. Many people are dying and my husband has been fired. We have three babies, but I have faith in her as she always listens to me'.

Color symbolism is central to the folk faith and Santa Muerte statues and votives are believed to have specific uses according to their color. There are three main colors associated with Saint Death: red, white and black. Red is utilized for petitions related to love, passion and lust. The black votive is employed for protection but is also notorious for its associations with black magic and vengeance. White candles are used for cleansing and blessing, as well as instilling peace and harmony. Purple candles are usually related to health but may also be used to work magic.

Judging by the sparse number of purple votive candles at Santa Muerte altars and shrines, one would suppose that miracles of recovered health do not figure as a central part of the cult. Looks are deceiving. Many devotees seeking healing or giving thanks for restored well-being light white or yellow candles instead of the newer and less popular purple ones. Both yellow and amber candles have a specific association with recovery from substance abuse, while white tends to be employed for a plethora of health problems. That not only one color but three different hues of candles are associated with the quest for health reveals the paramount importance of Holy Death's role as divine doctor. 
Devotees not only have set prayers at their disposal but also a number of rituals aimed at compelling Holy Death to cure their afflictions. For instance, La Biblia de la Santa Muerte (Rey 2009) offers five such rituals for healing. The 'ritual for health' typifies the genre:

\author{
1 medium stalk of rue \\ 1 meter of purple ribbon \\ 1 votive candle for health (purple) \\ 1 bottle of Santa Muerte lotion \\ 1 cigar \\ 1 maguey leaf \\ 1 black pen
}

\title{
Procedure:
}

Use the black pen to write down all your afflictions on the ribbon and then take the ribbon and tie the rue in a bunch. Sprinkle some of the Santa Muerte lotion over the rue. Light the cigar and exhale the smoke over the rue. Now use the rue to cleanse your entire body, beginning with your head and moving down to your feet, ensuring you pass the rue several times over your body part that is most affected. Upon finishing, wrap the rue in paper and dispose of it. Take the sharp tip of the maguey leaf and inscribe your full name along the width of the candle. Then cleanse your entire body with the wax, commencing with your head and ending with your feet, again ensuring to pass over the most ailing body part several times. Light your candle and recite the printed prayer. The flame should illuminate the front of your Saint Death statue. You may also put it on your altar, but always ask her to ensure your health.

This ritual would be most familiar to many devotees, since, save for the Santa Muerte lotion, both the ingredients and the ritual act itself derive from Mexican 'curanderismo' or folk healing practices. Syncretically drawing on Indigenous, Spanish and, to a lesser extent, African curing practices, curanderismo offers afflicted Mexicans a more holistic and economical alternative to Western medical care. As we will describe, it is also offered by the many curanderos who work with Santa Muerte, such as self-identified bruja (witch) and curandera, Yuri Mendez who works with herbs and prayer to heal devotees of ailments.

It is the Iberians who brought rue to the Americas, where it still serves the same purpose that it did on the Iberian peninsula, and even in ancient Greece. Just as garlic was employed to ward off vampires, rue was used in ancient Greece and in contemporary Mexico and much of Latin America to ward off witchcraft and the evil eye, which is a widespread belief among the working classes of the region. More than a few Mexicans also steep the bitter herb into a medicinal tea that is believed to cure a panoply of ailments including stiff neck, dizziness, headaches and inner ear problems. Thus, in the Holy Death healing ritual, rue serves as a cleansing sponge absorbing illness as it is waved over the body of the afflicted. Upon completion of the cleansing ritual, the rue is discarded to ensure removal of the negativity believed to be absorbed therein.

Two additional ingredients enhance the ritual cleansing potency of the rue. Given that purple is the main color for curing, the ribbon of this hue, which is knotted around the rue, augments the herb's healing power. It's the cigar, of all the curative ingredients, 
that has the most potent link to healing, in spite of its current notoriety as a carcinogen. Across the Americas, Indigenous peoples chewed, smoked and drank tobacco tea for intertwined spiritual and medicinal purposes. At present, cigars and cigarettes are common currency in both folk healing practices and African-diasporan faiths. We ourselves have had tobacco smoke blown over our bodies by Santa Muerte leaders and shamans during fieldwork in Mexico. In any case, for most practitioners of the Saint Death health ritual, the cigar serves as a powerful agent and symbol of healing.

Maguey, also known as the Century Plant, also connects Mexican Santa Muertistas to their pre-Columbian heritage. The plant was employed by the Aztecs for a range of ailments, including gout and topical wounds. In addition, the Aztecs and other Indigenous peoples in central Mexico fermented the juice of the plant into an alcoholic drink called pulque, which contains a substantial amount of vitamin B and to this day is an important source of nutrition for a significant number of campesinos in rural central Mexico ${ }^{3}$.

Spanish colonists, interested in stronger tipple than pulque, distilled the juices of the blue agave plant and maguey into tequila and mezcal, respectively. However, in the Santa Muerte healing ritual, the Maguey leaf functions not as a medicinal ointment but rather as a writing instrument. The multi-purpose Century Plant thus serves as a key ingredient in this recipe for curing by lending its salubrious fibres for making an inscription in the votive wax. The mauve votive candle, like rue, also functions as a cleansing agent, soaking up affliction as it traces the corporeal contours of the petitioner. As the candle is left to burn at the altar of Doctor Death, the contagions absorbed in the purple wax are then ritually incinerated.

It is no coincidence that the deceased top Saint Death leader in Mexico, Enriqueta Vargas of Santa Muerte Internacional, had begun conducting funeral services at her temple in Tultitlán prior to her death. Having known her for several years, we were always surprised that she performed baptisms and weddings at her temple but not last rites. When we asked her in November 2015 why she did not offer funeral services she responded, 'People aren't ready for that yet'. The charismatic evangelist of Saint Death began conducting last rites at her temple only a few months later.

\section{The Coronavirus Candle}

Scholars describe Santa Muerte as the matron 'saint of the desperate', as she is primarily venerated by the poor and needy, who appeal to her to improve the precariousness of their lives (Torres-Ramos 2015, p. 139, see also Fragoso Lugo 2007, de la Fuente 2016, p. 169). At this time, it is the impoverished who are most at risk of succumbing to Covid or who are facing the ramifications of stern measures that entail they can no longer conduct business. The poor may be unable to social distance or stay at home as their jobs require them to deal with the public and thus many are turning to the saint of death to protect them in these times of pestilence. Some also work in the medical profession and are working with COVID-19 patients daily and gifting Santa Muerte offerings in order to build a rapport that keeps her content so she does not cart them off.

\footnotetext{
3 'Yo le he pedido que el Coronavirus se vaya, yo tengo fe en ella. Esta muriendo mucha gente y a mi esposo lo despidieron. Tenemos tres bébés pero yo tengo fe en ella porque siempre me escucha'.
} 
The Saint's astonishing adaptability to the Mexican religious marketplace and her important role as doctor death is visible by browsing the paraphernalia with her image on them. Even before the pandemic erupted, hundreds of shops selling esoteric items across the country were kept afloat by brisk sales of Santa Muerte paraphernalia (Chesnut 2017, p. 6, 48, 66). Manufacturers and retailers of Saint Death products have responded with impressive celerity to the new market for protection and healing from COVID-19. The latest of these are the coronavirus candles with Santa Muerte's picture on them and the wording 'protección contra Coronavirus' (protection from coronavirus).

According to Verónica Lezama, the owner of a shop that sells esoteric goods in Villahermosa, Tabasco, Productos Esotéricos San Gabriel, the Holy Death coronavirus candle has been selling extremely well (Fig. 1). It is sold alone but it is also offered as part of a kit that also includes a lotion and a balm. The candle, it is advised, should be inscribed with the name of the person seeking protection from the virus, or ailing from it. They should then touch it to their body before lighting it. The balm is to be rubbed on the body for apotropaic effect. The lotion, we were told by devotees, is used at door lintels to protect the inside of the home and its inhabitants from coronavirus.

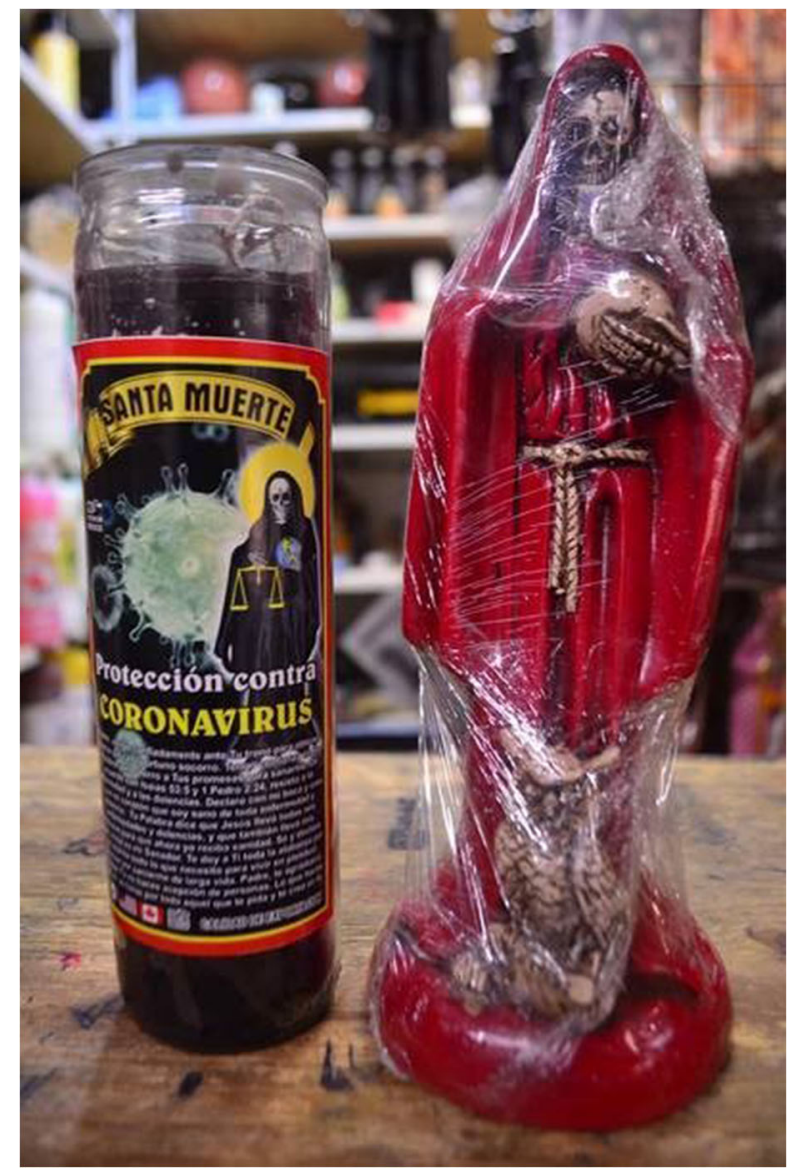

Fig. 1 Santa Muerte candle for protection from Coronavirus 
In southern Mexico, in the state of Oaxaca, the coronavirus lotion is not available, but a general, all-purpose Santa Muerte lotion is. It is said to have shielding properties. Margarita, 35 years old and a devotee of Santa Muerte, owns a small shop near Pochutla. She hears daily on the radio news announcers extolling the new coronavirus prevention motto 'quedaté in casa' (stay at home) but she has not shut down her store, nor stayed at home. Her storefront where she sells women's knick knacks, from hair grips to earrings, is her only income and with her husband out of work due to COVID19 she is now the sole breadwinner for the family.

Concerned about a client passing the virus on to her, Margarita has turned to supernatural measures for protection. She related how she sprinkled Santa Muerte lotion outside her storefront to prevent COVID-19 from entering. So far, she stated, it seemed to have worked. She explained 'death is even more powerful than God himself', and the only way to avoid falling into her bony embrace is to 'pray daily to Santa Muerte, give her offerings and purify your home and business'. Like Marisela, she too has a modest shrine featuring a few gem stones, a glass of water, some flowers she collected from nature and one small Santa Muerte statue which is blue but for her the color is not important, what is vital is that she may speak to her folk saint daily through the effigy. The altar also features a picture of her husband whose health is poor and whom she worries about. By placing his image on her small shrine, she explained 'Santa Muerte will protect him'.

\section{Folk Saint Faith Healing}

Although the Biblia de la Santa Muerte is widely used by devotees, new chap books with novel prayers are constantly circulating and this evinces, once again, to the malleability of the new religious movement in shifting circumstances. A prayer of protection from COVID-19 was sent to the anthropologist by Yuri Mendez, a self-identified witch, curandera and shaman of Santa Muerte whom she had visited in Cancun shortly before the lockdown commenced. Yuri Mendez has been praying weekly to Santa Muerte and giving her offerings. She has supplicated the saint not only for protection for herself and her family from coronavirus but also petitioned her for world healing. She is also concerned for her husband who previously worked as a carpenter. He has now lost his job due to measures to prevent the spread of COVID-19 which entails many businesses have been forced to close their doors. Fortunately, Mendez offers a range of shamanic services to clients so has been able to make ends meet.

Yuri related how many people were now suffering in Quintana Roo. The area is entirely dependent upon tourism, and only those in the smaller sectors of fishing and agriculture have been mostly unaffected. Due to coronavirus, hotels and beaches have been closed and tourists have no longer been flooding the area with their American dollars. Innumerable people have been furloughed from their jobs and are struggling to support their families. The press stated that over 80,000 people had lost their jobs, and we should note that those figures do not count those working in the informal economy (Vasquez 2020). Furthermore, coronavirus is fueling crime as many have turned to illegal methods to ensure their survival.

Yuri dressed her numerous effigies of the skeletal folk saint in gowns and translucent veils of mauve and lemon, as well as gifting the saint blooms and vegetables of 
these colors associated with sanation, such as yellow gourds and eggplants. After lighting purple, white and yellow candles of healing and wafting burning bundles of rosemary and sage leaves in her chapel, which she states are purifying, she recited the prayer that follows, which we have translated from Spanish. She invited her many followers, also devotees of death to join her, posting pictures of her altar. She related how she prayed while visualizing the folk saint using her scythe to clear the earth of coronavirus, in particular on days when the moon was waning such as the 16th March and 14th May (Fig. 2).

Santa Muerte, Lady of the Light

Before God and before you I kneel so that

You Intercede for me and for the entire world

To eliminate all evil, virus or bacteria

Cleanse with your purifying mantle.

Lady listen to my pleas.

Help and give bread and shelter to those who need it

And seek in you strength

Lady of the End Times protect us so that we are not infected.

And do not infect those we love

Sweep COVID-19 away from our path

And grant us shelter, food and support

I ask you to never fail me

Amen.

Yuri detailed that her clients, friends and family had also turned to her to ask advice on how to propitiate Santa Muerte for protection against coronavirus. She has been recommending that they place an eggplant on their altar due to its color. As we have seen mauve is associated with the healing powers of Santa Muerte. Much as ancient Greeks offered garlic to the goddess Hekate associated with the underworld, magic, witchcraft and necromancy, Yuri has also been gifting her saint and recommending other devotees of death give Santa Muerte the pungent bulb in a quid pro quo with death for life.

Devotees of Santa Muerte are not necessarily exclusive to the saint and also invoke other figures as necessary in their petitions. Yuri decided to bring a special guest to her shrine since COVID-19 commenced, whom she believed would give la Santa a helping hand in her mission of world healing, 'el Niño Doctor' (the Child Doctor). Among the multiple advocations of the Christ Child in Mexico, el Niño Doctor stands out for his healing powers (Scheper Hughes 2012). Traditionally, he is bedecked in an oldfashioned white physician's smock, but on Yuri's altar, the Child Doctor features in a modern medic's turquoise outfit replete with scrub cap and a surgical mask covering his mouth (Fig. 3). He is especially sought out for the healing of ailing Mexican children. In churches across the country, but especially in the Mexican capital, his statues are often graced with offerings of toys, ex-votos for miracles of restored health that he is believed to have granted to the faithful. His novel presence at the Santa Muerte temple in Cancun bespeaks the intense fear over the virulent pandemic currently peaking in Mexico, which as of August 2020 ranks third in Coronavirus deaths 


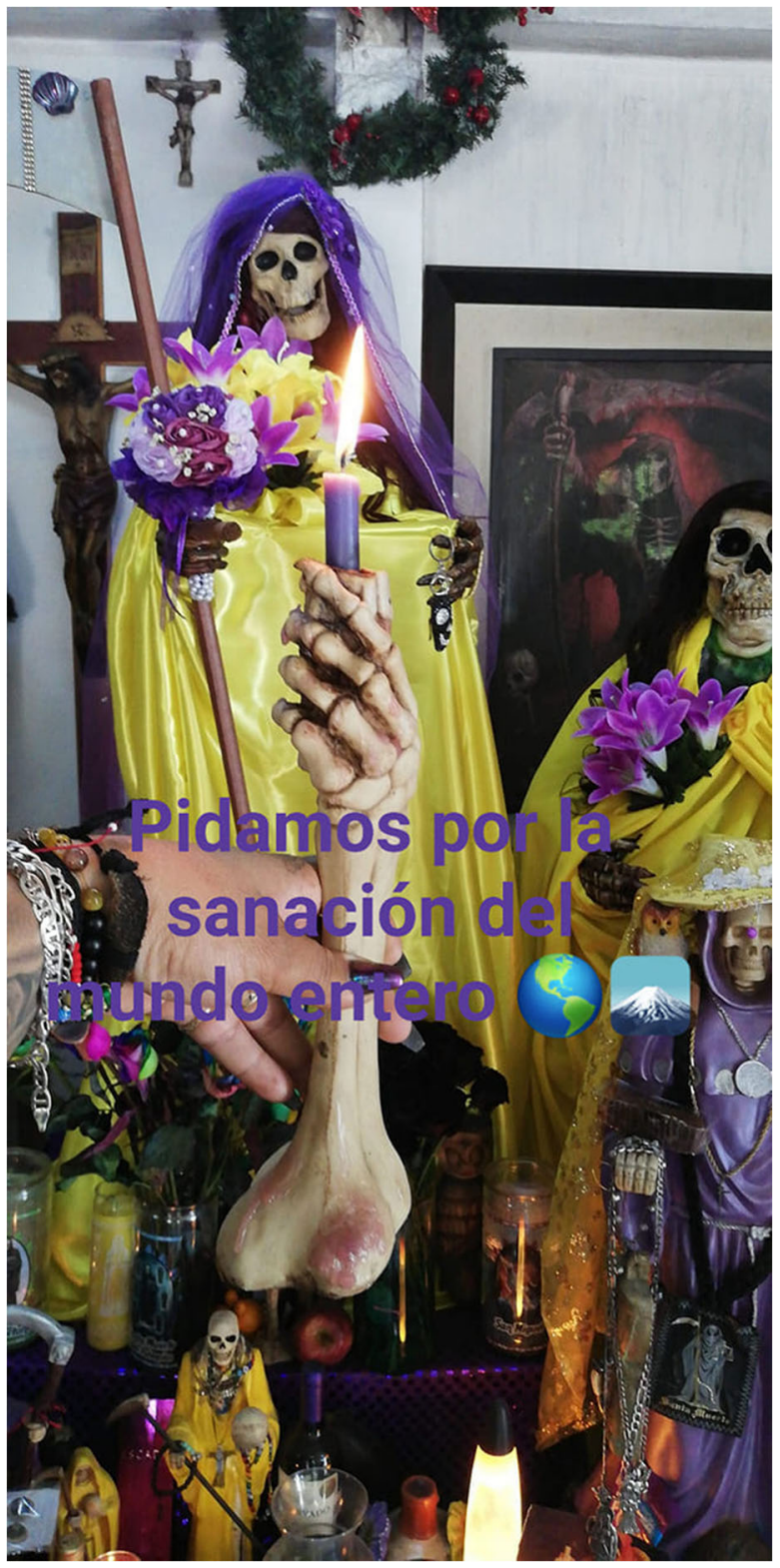

Fig. 2 Yuri Mendez's Santa Muerte statue named Yuritzia dressed in a veil of purple and a gown of yellow, colors associated with healing. She extends a mauve candle of sanation in her hand as she prays; the caption states: Let us ask for world healing

after the USA and Brazil. Even Holy Death, one of the most powerful healers on the national religious landscape, needs some supernatural assistance in protecting from and healing those suffering from coronavirus.

Shortly before we were due to submit this article, Yuri was in contact to say that Santa Muerte had performed a miracle of coronavirus healing. A family residing close 


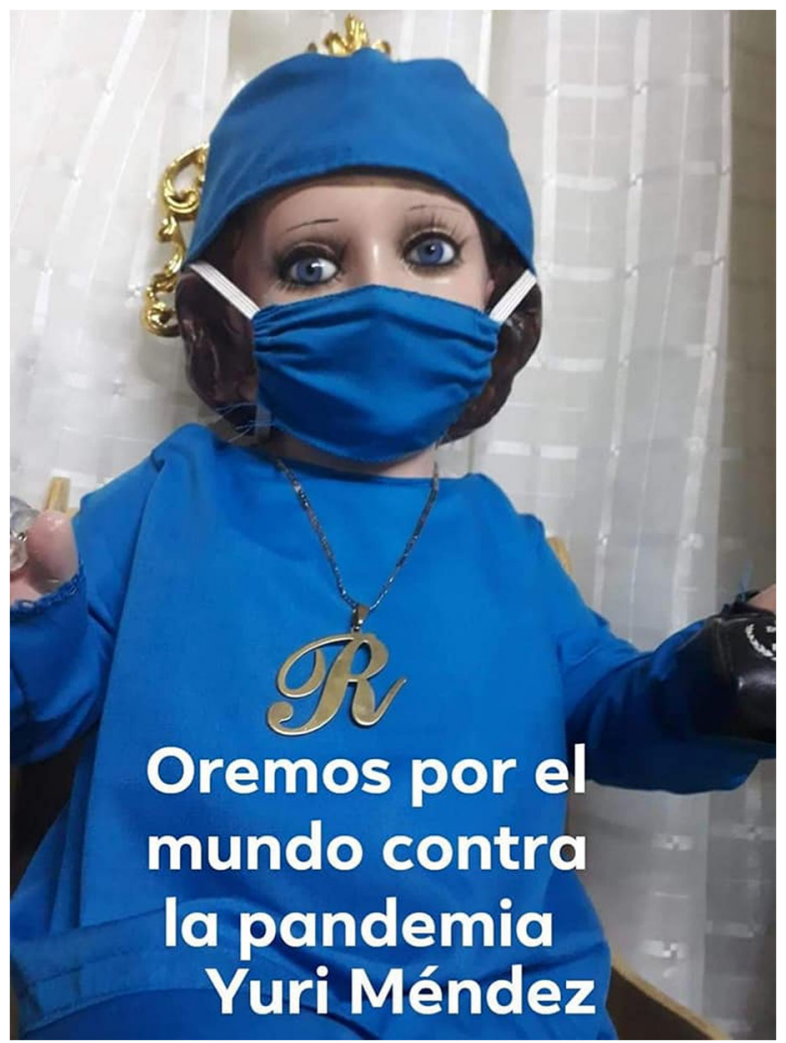

Fig. 3 Niño doctor with a statement by Yuri on this photo which she took: Let us pray for the world against the pandemic

to the shrine with their young daughter were diagnosed with the virus. Camila, the mother, messaged Yuri to ask her to pray for their family. Camila also asked her to light votives for her and husband Diego, and their daughter Ana Fernanda. Yuri was unable to obtain the Santa Muerte coronavirus candle in Cancun. Nevertheless, she did find a COVID-19 votive that featured a plea to the archangels.

Yuri lit two candles, placing one for the young girl before el Niño Doctor with an offering of cookies, and one before Santa Muerte for Camila and Diego with gifts of flowers and sweet breads. She prayed for the ailing couple's family, both privately and publicly, including during the monthly rosary on June 1 ${ }^{\text {st }}$, when many assemble at her chapel. As detailed, Yuri is a Santa Muerte curandera and recommended a herbal tea to be imbibed thrice daily consisting of oregano, lemon, garlic, bougainvillea and cloves. Within a week, the family had recovered their health and to thank the folk saint gifted her lavish bouquets of white flowers, white candles and paid for a mariachi band to sing odes to the salubrious saint. Yuri also thanked Santa Muerte with prayers and further offerings.

Studies of Marian devotion and Latin American folk saints have provided strong evidence that prayer, curanderismo and religious rituals have psychological benefits (Ortiz and Davis 2008). It is noted that such actions - which devotees believe gives them support from a supernatural being - augment hope, bring peace of mind and the 
strength necessary to cope with and even overcome difficulties. We should surmise that religion has an important role for coping with coronavirus and that the imagined supernatural aegis of Santa Muerte may also have positive impacts on healing.

\section{Supplications to la Santa}

Prayers of healing like Yuri's, both written on actual prayer cards or appearing as virtual prayer images in places like Facebook, have been circulating in Mexico since the first cases of coronavirus struck Mexico (Fig. 4). Much as Santa Muerte has been erroneously depicted as a narco-saint appealed to only by drug criminals to hex enemies (Chesnut 2017; Kingsbury and Chesnut 2020a), many prayers in actuality are for the care of loved ones. They appeal to her as an angel sent by God to heal and help, such as this prayer recommended in a chapbook being sold across Mexico, often in conjunction with the coronavirus candle for ailing family and friends. It reads as follows:

Santisima Muerte, My Lady, Angel that God our Father created to help and serve

Today I implore and supplicate please grant me healing and save the life of (insert name)

That their days on earth be many

That their body recover vim and vigour,

You who are all powerful, save him/her

And ensure they recover their health.

I implore you on this day, at this time

For Jesus Christ our saviour on the Cross,

Please act and return safely him/her to full health and well-being.

Amen.

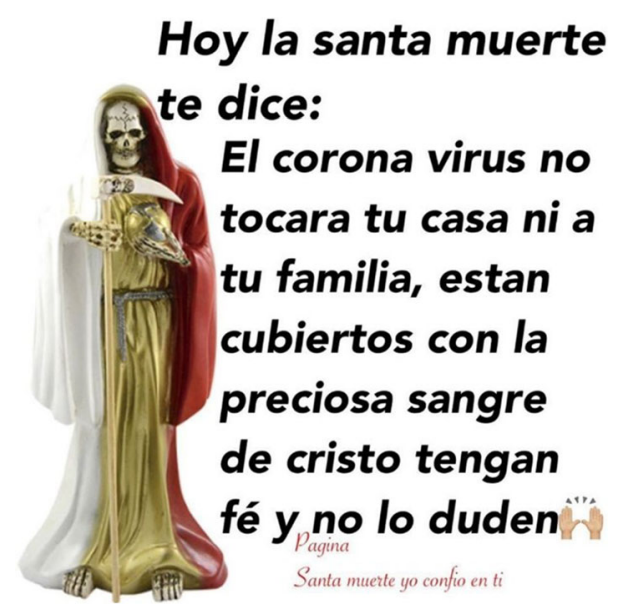

Fig. 4 Prayer card 
Even beyond Mexico, in migrant communities, in places like Texas, Mexican devotees have been praying to the folk saint, supplicating her for global supernatural sanation. This once again counters the narco-saint rhetoric, evincing that devotees turn to Holy Death for allocentric purposes. In response to public demand the Basilica Santa Muerte, a church dedicated to the Skeleton Saint in Los Angeles posted on their website and on YouTube videos which garnered over nine thousand views, featuring prayers for world healing from COVID-19, both in Spanish and in English, such as this one:

Oh Divine Holy Death,

You are always in our path

As a sign of salvation and hope

As a symbol of the end of pain and suffering

Today we approach you with a plea

We ask you for peace in the world

And healing for the sick,

We ask you with the power of your scythe

Sever once and for all the shadow of Coronavirus

We are not afraid of death

But neither do we want to leave at this time

We want one more opportunity

To demonstrate to ourselves

That we are capable of moving forward

Without so much hatred or evil in our hearts

I implore you, I beg you,

Wipe out this cursed illness,

Wipe out coronavirus,

Make it disappear from the face of the earth,

Open the eyes and hearts of all who see this prayer,

So that they know the great power you have.

Amen.

In both this invocation and that of Yuri Mendez, we should note that Santa Muerte's accoutrements are essential to how devotees imagine her offering them supernatural aegis. Her mantle features frequently in accounts as purifying and protecting both individuals and the world in general. Enriqueta Romero, the owner of the famous Tepito shrine, detailed in a documentary by Eva Aridjis (2012) how Santa Muerte offered her mantle to hide her from criminals. They wanted to mug her on her way home late one night from the hospital where her son was lying wounded after a gunfight. But in the context of health and healing, the mantle offers another sort of protective cover, one that shields devotees from the virus and also purifies the space around them as Yuri's words 'cleanse with your purifying mantle' attest.

In $90 \%$ of her iconography, Santa Muerte is depicted wielding a scythe in her right hand. In Mexico, much as in the European mythology that was earlier analysed, this represents her role as she who reaps souls, nevertheless devotees of Santa Muerte, have imbued the implement and concomitantly la Santa with 
new abilities. The guadaña or scythe is said by devotees to be able to rid spaces and even people of negative energy. Lina, a devotee of death who the anthropologist met in Oaxaca had described the scythe thus, "the guadaña can cut away bad energy, this may be in the form of enemies, bad influences or envy' but additionally as we see in the above prayer which states 'with the power of your scythe, cut once and for all the shadow of coronavirus' the scythe is also believed capable of cleaving away illness and disease which is another manifestation, in the eyes of many devotees of negativity and evil.

\section{The Angel of Death as Defender of Front Line Workers}

Vivian is a nurse from Veracruz who works on the front line with COVID-19 patients. Daily she dons a silver chain with a pendant that depicts Holy Death. She believes that this shields her. She has an altar in her house that consists of three statues, the white Santa Muerte statue of cleansing and harmony, the gold Santa Muerte statue of riches and abundance, as well as a black Santa Muerte statue. At the centre of the shrine is a censer in which she burns sage with roses and copal. This area is also where she burns candles. All around it are offerings which she renews every 2 weeks to every month.

Vivian explained the offerings to us 'She likes fresh flowers, especially pink flowers. She also asks for fresh tequila, and wants her apples with cinnamon. I also give her cologne, Agua de Florida. She loves Roses'. Agua de Florida was created in New York City by David Lanman and Robert Murray in 1808 in response to the European vogue of the 1700 and 1800s in European society of 'Eau de Cologne' or Cologne Water. It contains alcohol, water and essential oils of bergamot, neroli, lemon, cloves, cinnamon, lavender, rose and orange flower. It gained popularity around the country, spread to Latin America, and even ended up in remote villages being used by shamans in ceremonies in the Amazon. It is used in cleansing rites and spells to remove unwanted energy, and many use it akin to holy water for cleansing and protection which is how Vivian uses it.

Vivian related that she appeals in particular to her Black Santa Muerte statue. Although commonly associated with hexing and vengeance - especially in the media which link the candle to narcos and their nefarious activities - black Santa Muerte's role also extends to protection which the nurse claimed that the folk saint has blessed her with. Santa Muerte, as we have described, is a laissez-faire faith characterized by heteropraxy, thus unlike Yuri, Vivian does not offer Santa Muerte any special gifts specifically for fighting COVID-19, nor does she read out any ad hoc coronavirus prayers, but simply asks the saint to proffer her protection as well as reciting Our Fathers and Hail Mary. Nevertheless, Vivian told me that she is aware that she is at risk of catching COVID-19 given that all day long she tends to those ailing from it. She stated 'when I feel something weird in my throat I drink a shot of tequila at her altar with her'. This she believes cleanses her body, ridding it of the virus.

Vivian related that she did not fear death and had had discussions with Holy Death at her altar telling her that if it was her time that she could reap her soul, but she hoped that if not the saint would make her strong so she could live another day. As to those dying, sometimes in her presence at the hospital where she works, she calmly stated: 'it is mostly the elderly who are dying and the way I see it she is just taking people because it 
is their time to go'. The belief that we all have an appointed hour of our death is common in Mexico and captured by the popular refrain, 'cuando te toca te toca' (when it's your time to go, it's your time to go).

\section{Attitudes to Death in a Time of Coronavirus}

Many Mexican devotees of death that we spoke to have a positive and accepting attitude towards death. In contrast, Europeans and Americans during the past century have generally regarded death as inimical, a spoiler of the American Dream. Death is seen as finality and for some may even be a taboo topic. Only recently with the advent of death positive movements, such as 'The Order of the Good Death' have some begun to address their mortality in a more affirmative fashion. Memento mori motifs are an important part of Christian iconography featuring in many churches and cemeteries across Europe. They evoke the Christian's faith's attitude towards death. They feature skulls, hourglasses and other items that serve not only as a reminder of the brevity of life but to extol the necessity of leading an ascetic lifestyle punctuated by prayer to prevent punishment by hellfire.

In much of Mesoamerica the skull was a symbol not of impermanence, but rather the never-ending cyclicity of life and death which were considered inextricable. It also manifested the relationship between death and power (Lomnitz 2005, p. 166). In Aztec culture, for example, it was believed that the dead transferred their life force into the land upon their passing, thus fertilizing it which in turn strengthened the state and its people, thus assuring the perdurance of the living. As such death was not about brusque finality, as it is in much of European and American culture, but about continuity, community and the cycles of the cosmos. Santa Muerte, as we saw earlier in this article, is a syncretic saint who in part takes from pre-Hispanic thanatological epistemologies and as such she is not only petitioned by devotees for protection but as we saw in the case of Vivian, also provides a cultural framework within which to accept death's bony embrace when she inevitably appears with her scythe to reap one's last hour.

\section{Conclusion}

As we reflect on Santa Muerte's role as a supernatural protectress and curandera in these times of pandemic pestilence, we underscore several important final points. Firstly, the mass media have, with few exceptions, systematically ignored her status as one of the most important healers on the Mexican religious landscape. TV networks and newspapers focus on the black Santa Muerte candle of crime and violence, selling the sordid and sensational in order to gain more viewers and readers (Kingsbury and Chesnut 2020a). However, whether in her white, yellow, purple or even black form, as we saw in the case of Vivian, devotees imagine that she protects and cures them from coronavirus, asking not only for healing for themselves but also for loved ones and even world healing.

Secondly, evincing the importance of religion as a coping mechanism in times of pandemic, Santa Muerte's healing powers have found great new demand in the Mexican religious marketplace in the midst of COVID-19. Evidence from previous 
work (Beattie 1964; Ortiz and Davis 2008) suggests that religious and spiritual rituals are cathartic, contributing to positive psychology and we propose that currently Santa Muerte rites and prayers may be helping to cope mentally with the mental and physical stresses caused by the threat of and infection from coronavirus. Yet as we point out Holy Death's very origins are linked to the plague not as a holy healer but as a symbol of loss and finality.

The saint's role as curandera in a time of pandemic may prima facie appear paradoxical if we only consider the saint's European heritage or contemporary origins, as Lomnitz (2005) or Kristensen (2014) have done. It is thus vital, as we have demonstrated, to trace her pre-Hispanic origins to understand death as a source of life. The duality of the saint's powers hails from an Indigenous ontology that presupposes the interdependence of life and death, and also assumes that death deities may intervene in earthly causes, including prolonging life. Only by decolonizing our knowledge of Santa Muerte's origins and accepting her significant pre-Columbian derivation can we understand the role of the death saint who at once heals the ailing but also snips the thread of life and snatches up souls, while providing a thanatological epistemology for understanding mortality. Santa Muerte is imagined by devotees not only as a reaper of souls but as simultaneously warding off disease and mending broken bodies and in so doing she adds a few more grains of sand to the hourglass of life.

Acknowledgments We would like to thank Yuri Mendez, Abby A., Luna O. and the numerous other devotees of Santa Muerte for sharing their stories and rituals with us. We also express our gratitude to the Society for the Scientific Study of Religion for supporting our work with the Jack Shand Grant. Dr. Kate Kingsbury would like to extend her deepest thanks to Dr. Ruth Bryan for her interest in and the support of her work on Santa Muerte devotion which has been unwavering.

Funding information This study received financial support from the Society for the Scientific Study of Religion: Jack Shand Grant and Bryan Gruhn Fund.

\section{References}

Agostoni C (2018) Ofertas médicas, curanderos y la opinión pública: el Niño Fidencio en el México posrevolucionario. Anuario Colombiano de Historia Social y de la Cultura 45(1):215-243

Argyriadis, K. (2016). Panorámica de la devoción a la Santa Muerte en México: pistas de reflexión para el estudio de una figura polifacética in Alberto Hernández Hernández (eds.), La Santa Muerte. Espacios, cultos y devociones, El Colegio de la Frontera Norte-El Colegio de San Luis, México

Aridjis H (2012). La Santa Muerte. Alfaguara

Beattie JHM (1964) The Ghost Cult in Bunyoro. Ethnology 3(2):127

Bloch, Maurice, and Jonathan Parry, eds. (1982) Death and the regeneration of life. Cambridge University Press

Bramley W (1990) The gods of Eden. Avon Books

Brondos D (2001) Why was Jesus crucified? Theology, history and the story of redemption. Scott J Theol 54(4):484-503

Burki T (2020) COVID-19 in Latin America. Lancet Infect Dis 20(5):547-548

Cervantes M (1605) [2018]. Don Quixote. LBA

Chesnut RA (2017) Devoted to death: Santa Muerte, the skeleton saint. Oxford University Press

Chesnut RA, Kingsbury K (2019) Pentecostalism in Brazil. In Oxford Research Encyclopedia of Latin American History

Chesnut RA (2020) Praying to godmother death - new evidence of Santa Muerte venerated as 'Comadre Sebastiana' in 19th-century New Mexico. The Global Catholic Review (Patheos), July 25 
Cohn SK (2008) Epidemiology of the black death and successive waves of plague. Med Hist 52(S27):74-100

Cohn SK, Cohn SK (2003). The Black Death transformed: disease and culture in early Renaissance Europe (p. 10). New York: pantheon

Craffert PF (2010) The life of a Galilean shaman: Jesus of Nazareth in anthropological-historical perspective. ISD LLC

De la Fuente S. (2016) Entre niñas blancas en la colonia Ajusco, mirada etnográfica del culto a la Santa Muerte en el sur de la Ciudad de México in Alberto Hernández Hernández (eds.), La Santa Muerte. Espacios, cultos y devociones, El Colegio de la Frontera Norte-El Colegio de San Luis, México

Dietrich BC (1965) Death, fate and the gods: the development of a religious idea in Greek popular belief and in Homer. University of London classical studies

Harrington P (1988) Mother of death, mother of rebirth: the Mexican virgin of Guadalupe. J Am Acad Relig 56(1):25-50

Horrox R (2013) The black death. Manchester University Press

Hosier D (1995) Sound, color and meaning in the metallurgy of ancient West Mexico. World Archaeol 27(1): $100-115$

Fragoso Lugo PO (2007) La muerte santificada: el culto a la Santa Muerte en la ciudad de México. Revista de El Colegio de San Luis 9(26-27):9-38

Graziano F (2006). Cultures of devotion: folk saints of Spanish America. Oxford University Press

Guerra F (1964) Maya Medicine. Med Hist 8(1):31-43. https://doi.org/10.1017/S0025727300029070

Guthke KS (1999) The gender of death: a cultural history in art and literature. Cambridge University Press

Kingsbury K (2020) Death is Women's work: Santa Muerte, a folk saint and her female followers. International Journal of Latin American Religions 1-21

Kingsbury K, Chesnut A (2020) Not just a Narcosaint: Santa Muerte as matron saint of the Mexican drug war. International Journal of Latin American Religions 1-23

Kingsbury K, Chesnut A (2020b) Santa Muerte: 1'Amour et la Mort. Anthropologica 62(2):1-30

Knoll SA, and Oosterwijk S (Eds.). (2011) Mixed metaphors: the danse macabre in medieval and early modern Europe. Cambridge Scholars Publishing

Kristensen RA (2014) How did Death become a Saint in Mexico?. Ethnos 81(3):402-424

Jansen M, Jiménez GAP (2017) Time and the ancestors: Aztec and Mixtec ritual art. Brill

Lewis O (1961) The children of Sanchez: autobiography of a Mexican family. Vintage

Lind M (2015) Ancient Zapotec religion: an ethnohistorical and archaeological perspective. University Press of Colorado

Lomnitz C (2005) Death and the idea of Mexico. Zone books

Malvido E (2005). Crónicas de la Buena Muerte a la Santa Muerte de México. Arqueología mexicana 13(76): 20-27

McCafferty, G. G., \& Carrasco, D. (2001). The Oxford encyclopedia of Mesoamerican cultures

Megged A (1996) Exporting the catholic reformation: local religion in early-colonial Mexico (Vol. 2). Brill

Miller, M. E., \& Taube, K. (1997). An illustrated dictionary of the gods and symbols of ancient Mexico and the Maya (p. 115). Londres: Thames and Hudson

Ortiz FA, Davis KG (2008) Latina/o folk saints and Marian devotions: popular religiosity and healing. In McNeill, B (eds) Latina/o healing practices: Mestizo and indigenous perspectives 29-62

Pansters WG (Ed.). (2019) La Santa Muerte in Mexico: history, devotion, and society. University of New Mexico Press

Perdigón Castañeda JK (2008) La Santa Muerte, protectora de los hombres. Conaculta, Instituto Nacional de Antropología e Historia, México

Pessar PR (2004) From fanatics to folk: Brazilian millenarianism and popular culture. Duke University Press Pollard HP (1993) Tariacuri's legacy: the Prehispanic Tarascan state. University of Oklahoma Press, Norman Rey, V. (2009) La Biblia de la Santa Muerte. Calli Casa Editorial

Roush L (2014) SANTA MUERTE, PROTECTION, AND "DESAMPARO": a view from a Mexico City altar. Lat Am Res Rev 49:129-148

Hughes JS (2012) The Nino Jesús doctor: novelty and innovation in Mexican religion. Nova Religio: The Journal of Alternative and Emergent Religions 16(2):4-28

Schele L, Freidel D (1990) A Forest of kings: the untold story of the ancient Maya. William Morrow and Company. Inc., New York

Schmidt SK (2011) 9. Memento Mori: the deadly art of interaction. In Push Me, Pull You (pp. 261-294). Brill Steele TJ (2005) The Alabados of New Mexico. UNM Press

Sonne O. (2016) Plague, rats, and ships the realisation of the infection routes of plague. Dan Medicinhist Arbog 2016;44:101-133 
Tavárez, D. (2011). The invisible war: indigenous devotions, discipline, and dissent in colonial Mexico. Stanford University Press

Toor F (1947) A treasury of Mexican folkways. Crown, New York

Torres-Ramos G (2015) Un culte populaire au Mexique: la Santa Muerte. Socio-anthropologie 31(2015):139150

Rivard JJ (2012) Cascabeles y ojos del dios maya de la muerte, Ah Puch Estudios de cultura maya, 5

Van Marle R (1971) Iconographie de l'art profane au Moyen-Age et à la Renaissance: La vie quotidienne (Vol. 1). Hacker art books

Vasquez J (2020) En Cancún, 30\% de los trabajadores fue despedido: CROC, El Economista

Yllescas Illescas JA (2016) La Santa Muerte ¿un culto en consolidación? in Alberto Hernández Hernández (eds.), La Santa Muerte. Espacios, cultos y devociones, El Colegio de la Frontera Norte-El Colegio de San Luis, México

Zavaleta A, Salinas Jr A (2009) Curandero conversations: El niño fidencio, shamanism and healing traditions of the borderlands. AuthorHouse

Publisher's Note Springer Nature remains neutral with regard to jurisdictional claims in published maps and institutional affiliations. 